\title{
Reflections and focal points for critical intercultural communication
}

\author{
Jolanta A. Drzewiecka \\ Invited paper
}

\begin{abstract}
Received 29 April 2021; revised version received 22 June 2021; accepted 23 June 2021. Corresponding author: Jolanta A. Drzewiecka, Università della Svizzera italiana, Switzerland(drzewj@usi.ch).
\end{abstract}

It seems fitting to start with a biographical note. I am a relatively recent retransplant to Europe. Decades ago, I moved from my native Poland to the USA to complete my Bachelor studies at Humboldt State University in California, and then Master's and $\mathrm{PhD}$ at Arizona State University. After having lived more of my life in the USA than in Poland, I began visiting Switzerland, and moved here permanently. I taught at the University of Zurich as a Visiting Professor and, five years ago, took a position as Professor and Chair of Intercultural Communication at Università della Svizzera italiana in Lugano. Here, I have the privilege of working with the European Masters of Intercultural Communication, an Erasmus program that brings multi-university students together to the campus of one of the participating universities each Fall semester.

Can I really say that I am a transplant? When I left Poland, a central European country, it was barely considered to be European. It was imagined, instead, as part of the eastern borderland, the European internal other behind the Berlin Wall. Now, it is part of the European Union, which gave me a privileged position in applications for residency status in Switzerland. EU free movement has created a sense of a much more connected Europe, even though the Central and Eastern European countries still tend to be perceived as 'new' Europe, 'not quite' European, or 'Europe in becoming'. Their embracement of right-wing xenophobic politics is not helping the matter. The refusal of Visegrad countries to admit refugees arriving in 2015 revealed the depths of xenophobia and ethnic national primordialism arising on the rubble of state socialism and disappointment that capitalism did not deliver on its promises. However, in the rest of Europe, fences, fortifications, and hotspots against those seeking refuge from war and dire economic poverty, as well as numbers of people still languishing in camps in Italy, Greece, France, and elsewhere, are not exactly evidence of humanitarian higher 
ground. Fortress Europe has been fortifying and securitising, the privilege of its internal mobility protected from those on the outside. The fear or hostility towards refugees was driven by the outside having already been inside, repressed by revealing itself in coloniality. The internal cleavages between those demonstrating solidarity by welcoming and assisting refugees and those recoiling in fear towards nationalism are deep. I despaired, feeling that decades of teaching intercultural communication had failed.

Is intercultural communication helpful in responding to many problems we are facing such as migration movements, a turn towards populism and nationalism, and exposing racist violence by police in the US that prompted recognition of racism in many countries around the globe, including Switzerland? Some incidents of violence, purportedly in the name of Islam, have fuelled exclusionary discourses against migrants who are Arabic and/or Muslim, these categories often being conflated, animated by the ongoing identification of Muslims with Islamists. Alarmingly, the British Women and Equalities Minister, Kemi Badenoch, stated in her speech to the British parliament that 'We do not want teachers to teach their white pupils about white privilege and inherited racial guilt'. In response, an astounded teacher wondered in the Guardian how she is supposed to teach her minority students who bring up discrimination they are facing daily (Anonymous, 2020). What does the field of intercultural communication have to offer in the face of these and other problems?

The field's more recent turn towards critical nonessentialism animates complex analyses of interactions and more sophisticated understanding of differences and identities. However, received conceptions of cultural differences are too often abstracted from contexts of social life, power relations, and material structures. Here, attention to theoretical developments in related academic disciplines would help develop teaching of intercultural communication from a critical perspective in Europe. While critical intercultural communication has been developing in the USA for some time (Nakayama \& Halualani, 2011), much work is yet to be done to transfer its principles to European contexts and develop new insights. In particular, questions of diversity, race, and decoloniality should be discussed in the classroom as they address critical current social processes. Below I offer brief reflections on these focal points.

\section{Diversity within nation-states}

I have been working with many students who are curious and eager to understand intercultural dynamics. Many of them come to class with a desire to decentre their cultural experiences but think about intercultural communication as primarily inter- 
national. Focusing on negotiation of differences within national contexts is a critical move when intercultural communication is predominantly thought of as international. At stake is not only deconstructing the connection between nation and culture, but also understanding power relations among groups in the context of politicians' claims to 'failed multiculturalism', masking their failure to address segregation and exclusions. There is a tendency in European contexts to think of diversity primarily in gender terms and to categorise people who are not white as 'immigrants', 'people of immigration background', or 'second generation immigrants', thus denying internal diversity and resisting revision of white national identity. It is thus important to move towards recognition of diversity as intersectional and shaped by differential power effects (El-Tayeb, 2011; Lentin, 2020; Wekker, 2016). This means addressing stereotypes, prejudices, and structural inequalities as well as recognising the historical background of colonialism. This is an important step towards helping our students build self-awareness of their position within relations of power. While the Black Lives Matter movement spread outside of the United States and helped increase awareness of the pernicious effects of systemic racism, our challenge now is to make sure that our students do not project racism on the United States but learn to recognize and act against exclusions in their everyday lives. Too often people of colour are assumed to be immigrants and not citizens. These and other systematic and systemic exclusions have to be interrogated, and we need to begin talking about fair representation and inclusion in schools and workplaces.

The field of Intercultural Communication could benefit from engaging with the field of diversity studies as well as policy studies. For example, Steyn's (2015) Critical Diversity Literacy framework is a useful set of coordinates for recognising and analysing social inequalities distributed along axes of difference. While her work is enlightening in many respects, one of its tenets is particularly instructive, and that is the ability to recognize and read emotions around issues of diversity. Ahmed's foundational work on race and emotions is particularly helpful here (Ahmed, 2004, 2019; see also e.g., Andreassen \& Vitus, 2015; Bonilla-Silva, 2019). From a different angle, the work of Zapata-Barrero (2016) on the intercultural communication policy paradigm offers a useful starting point for thinking about the role of intercultural communication in diverse societies and their institutions. Engaging with this work critically would help our students to think about how their future careers can contribute to building cohesive societies. 


\section{'Race' as a significant category of difference}

While religion is at the centre of most discussions about migrants in Europe, 'race' is cloaked as culture and then muted in public discourses. Many Europeans seem to have a great reluctance to address 'race'. The displacement of 'race' and racism onto the colonies, and the resort to racelessness post WWII as a remedy for genocide and racism, led Europeans to avoid mentioning race as well as to disregard racial discrimination (Goldberg, 2006). To many, even mentioning 'race' seemingly creates problems and divisions. Many also suffer from an illusion that there are no racial problems in places that did not have colonies, such as Scandinavia or Switzerland. But this created 'a problem with no name' that is now being recognised on a broader social level (Goldberg, 2006). And contrary to the social muteness, some of the most important theoretical work about race and racism was developed by European scholars including Philomena Essed, Teun A. van Dijk, Colette Guillaumin, and Michel Wieviorka. While their work is widely relied upon in the USA, along with the more widely known British scholars Stuart Hall and Paul Gilroy, it has not been taken up as much in Europe or has faced outright hostility and denials of relevance (van Dijk, 2002). Critical Intercultural Communication should take up the contributions of these scholars as well as the more recent work to address how 'race' works as a technology of power and exclusion (Chun, 2009).

I find that my students are not only NOT opposed to discussing race but, while they might be uncomfortable, they are also curious. Recently, the curiosity has been augmented by the media spread of pictures of police violence in the wake of the video recording of George Floyd's death in the USA. This and many other cases demolished any last claims to post-racial societies. Many are beginning to recognise racist exclusions, but they fall back on either biological or essentialist terms. Thus, while insisting that races do not exist, it is imperative to engage with the social construction and the materialities of the racist organisation of society to equip our students with skills to decode how race and racism are encoded in different and changing forms in everyday conversations and media as well as the organisation of space (physical and virtual), economic relations, social practices, institutional exclusions, and so forth (M'charek, 2013). This critical attention to 'race' should include a focus on the specificity of invention and reconstruction of whiteness as a modality of power in European contexts (M'charek, Schramm, \& Skinner, 2014; Wekker, 2016). In spite of generations of people of colour born into European countries, European nationalities are still unreflectively tied to whiteness, thus exercising exclusion and marginalisation (Slootweg, van Reekum, \& Schinkel, 2019). It is vital for our students to think about whiteness not as an identity ascription, but a technology that takes multiple cultural forms and interpellates 
those who are ascribed as white into the ideology and technique of superiority. As a technology, race differentiates and constructs boundaries within the places where they live, thus perpetuating old colonial mindsets in new forms (Hervik, 2019; Lentin, 2019). Attention to 'race' and racism should not come at the expense of, but in connection to, other forms of oppression, such as patriarchy, heteronormativity, disablism, and classicism.

\section{Coloniality}

The importance of decolonising intercultural education has already been raised, albeit in the US context (Gorski, 2008). While some insights can be transferred to the European context, we also need to develop strategies and skills that speak to histories and cultural contexts specific to Europe. It is vital that we encourage our students to trace the colonial history of Europe to recognise how it has shaped enduring attitudes towards non-European peoples, that is, coloniality. While the UK and France have been recognising and forgetting their colonial past in waves (Stoler, 2011), other European countries, for example, Germany and Italy, are just beginning to acknowledge it. Others' tight hold on formally not having colonies is being challenged by work demonstrating not only the capital built in the colonies but also colonial beliefs in white European superiority. In Switzerland, for example, important work by Purtschert (2015) demonstrates the embeddedness of coloniality in shaping Swiss identity and attitudes towards non-Europeans.

While not so long ago my students had a difficult time recognising the relevance of colonialism to present day communication, I see this significantly changing. This is due at least in part to various decolonising projects, for example, decolonising museums as well as plentiful calls for decolonising academic disciplines. Last semester, several students proposed papers analysing colonial campaigns in France, enduring colonial attitudes in films, and coloniality in representations of the other in fashion advertising. Grappling with the past is important not only because it develops historical awareness, but also because the past lives on and demands recognition of its legacies in the present. The ongoing refuge seeking in Europe, hostility to refugees, along with insistence on 'European values' and construction of Fortress Europe, are all dramatic examples of how the living legacies of colonialism and neo-colonial practices are returning home to roost while being wilfully ignored as such. Such ignorance manifests itself in the debordering of Fortress Europe, the withdrawal of human rights from migrants, and the proliferation of boundaries in everyday life (Engelbert, Awad, \& van Sterkenburg, 2019; Rheindorf \& Wodak, 2020). 
Decoloniality is also crucial for understanding the relations between the Global South and the Global North. This involves deconstructing the North's approaches to development and 'the help' mentality which perpetuates economic inequalities and devaluation of local knowledge while masking continued exploitation. Under the guise of different vocabulary of social change and participation, the newer approaches to development have continued to marginalize local communities (Dutta, 2015). All predictions point to increasing migration due to wide ranging loss of habitat (Sassen, 2016). We thus urgently need to prepare young people to disrupt structures of domination, listen to the subaltern, and cocreate structures for a better future (Dutta, 2015).

\section{Conclusions}

Cultural self-awareness has been central to the teaching of intercultural communication. However, the field has for too long worked with notions of culture decontextualized from historical and economic contexts locally and globally, structures of domination, and questions of social justice. This limited selfawareness leads to, at best, benign culturalism and at worst to culturalist othering. Critical intercultural communication has to work with a robust understanding of power if it is to stay relevant in the context of polarisation between exclusionary nationalism and white fears on the one hand, and struggles for social justice on the other. The three focal points discussed above can provide a map for designing a critical intercultural communication curriculum and activities that will encourage greater awareness of the self in relation to others and skills for engagement. This was not the space to elaborate on these points and I do not claim to have done them justice. But I hope that my brief remarks will invite further discussion and thinking about what critical intercultural communication skills we need for the urgent challenges that are facing us currently and in the future. 
Journal of Praxis in Higher Education, Special Issue, Vol. 3, No. 2 (2021)

\section{Author biography}

Dr. Jolanta Drzewiecka is Associate Professor and Chair of Intercultural Communication at Università della Svizzera italiana. Her research focuses on discourses surrounding migration and public memories. She is currently directing a Swiss National Science Foundation project on Eritrean refugees in Switzerland. Her research has been published in Communication Theory, Journal of International and Intercultural Communication, Critical Studies in Media Communication, and other journals. 


\section{References}

Ahmed, S. (2004). The cultural politics of emotion. London: Routledge.

Ahmed, S. (2019). Strange encounters: Embodied others in post-coloniality. London: Routledge.

Andreassen, R., \& Vitus, K. (Eds.) (2015). Affectivity and race. Studies from Nordic contexts. London: Routledge.

Anonymous. (2020, November 19). As a teacher I need to be able to talk about racism without government meddling. The Guardian.

Bonilla-Silva, E. (2019). Feeling race: Theorizing the racial economy of emotions. American Sociological Review, 84(1), 1-25. https://doi.org/10.1177/0003122418816958

Chun, W. H. K. (2009). Race and/as technology; or, how to do things with race. Camera Obscura, 70, 7-35. https://doi.org/10.1215/02705346-2008-013

Dutta, M. J. (2015). Decolonizing communication for social change: A culturecentred approach. Communication Theory, 25(2), 123-143. https://doi.org/10.1111/comt.12067

El-Tayeb, F. (2011). European others: Queering ethnicity in postnational Europe. Minneapolis, MN: University of Minnesota Press.

Engelbert, J., Awad, I., \& van Sterkenburg, J. (2019). Everyday practices and the (un)making of 'Fortress Europe': Introduction of the special issue. European Journal of Cultural Studies, 22(2), 133-143. https://doi.org/10.1177/1367549418823055

Goldberg, D. T. (2006). Racial Europeanization. Ethnic and Racial Studies, 29(2), 331-364. https://doi.org/10.1080/01419870500465611

Gorski, P. C. (2008). Good intentions are not enough: A decolonizing intercultural education. Intercultural Education, 19(6), 515-525. https://doi.org/10.1080/14675980802568319

Hervik, P. (2019). Denmark's blond vision and the fractal logics of a nation in danger. Identities: Global Studies in Culture and Power, 26(5), 529-545. https://doi.org/10.1080/1070289X.2019.1587905

Lentin, A. (2019). Looking as white: Anti-racism apps, appearance, and racial embodiment. Identities: Global Studies in Culture and Power, 26(5), 614630. https://doi.org/10.1080/1070289X.2019.1590026

Lentin, A. (2020). Why race still matters. Cambridge: Polity Press.

M'charek, A. (2013). Beyond fact or fiction: On the materiality of race in practice. Cultural Anthropology, 28(3), 420-442. https://doi.org/10.1111/cuan.12012

M'charek, A., Schramm, K., \& Skinner, D. (2014). Technologies of belonging: the 
absent presence of race in Europe. Science, Technology, \& Human Values, 39, 459-467.

Nakayama, T., \& Halualani, R. (Eds.) (2011). The handbook of critical intercultural communication. Malden, MA: Wiley-Blackwell.

Purtschert, P. (2015). Colonial Switzerland: Rethinking colonialism from the margins. Basingstoke: Palgrave Macmillan.

Rheindorf, M., \& Wodak, R. (2020). Building fortress Europe: Legitimising exclusion from basic human rights. In M. Rheindorf, \& R. Wodak (Eds.), Sociolinguistic perspectives on migration Control: Language policy, identity and belonging (pp. 116-147). (Language, Mobility and Institutions). Multilingual Matters.

Sassen, S. (2016). A massive loss of habitat: New drivers for migration. Sociology of Development, 2(2), 204-233.

Slootweg, A., van Reekum, R., \& Schinkel, W. (2019). The raced constitution of Europe: The Eurobarometer and the statistical imagination of European racism. The European Journal of Cultural Studies, 22, 144-163.

https://doi.org/10.1177/1367549418823064

Steyn, M. (2015). Critical diversity literacy. Essentials for the twenty-first century. In S. Vertovec (Ed.), Routledge international handbook of diversity studies (pp. 379-389). New York \& Abingdon, OX: Routledge.

Stoler, A. L. (2011). Colonial aphasia: Race and disabled histories in France. Public Culture, 23(1), 121-156. https://doi.org/10.1215/08992363-2010-018

van Dijk, T. A. (2002). Reflections of 'Denying racism: Elite discourse and racism'. In P. Essed \& D. T. Goldberg, (Eds.), Race critical theories (pp. 481-485). Malden, MA: Blackwell.

Wekker, G. (2016). White innocence: Paradoxes of colonialism and race. Durham: Duke University Press.

Zapata-Barrero, R. (2016). Exploring the foundations of the intercultural policy paradigm: A comprehensive approach. Identities, 23(2), 155-173. https://doi.org/10.1080/1070289X.2015.1006523 